\title{
Cdk phosphorylation of the Ste11 transcription factor constrains differentiation-specific transcription to $\mathbf{G}_{1}$
}

\author{
Søren Kjærulff, Nicoline Resen Andersen, ${ }^{1}$ Mia Trolle Borup, ${ }^{2}$ and Olaf Nielsen ${ }^{3}$ \\ Institute of Molecular Biology and Physiology, University of Copenhagen, DK-1353 Copenhagen K, Denmark
}

\begin{abstract}
Eukaryotic cells normally differentiate from $\mathrm{G}_{1}$; here we investigate the mechanism preventing expression of differentiation-specific genes outside $G_{1}$. In fission yeast, induction of the transcription factor Ste11 triggers sexual differentiation. We find that Ste11 is only active in $G_{1}$ when Cdk activity is low. In the remaining part of the cell cycle, Ste11 becomes Cdk-phosphorylated at Thr 82 (T82), which inhibits its DNA-binding activity. Since the ste11 gene is autoregulated and the Ste11 protein is highly unstable, this Cdk switch rapidly extinguishes Ste11 activity when cells enter S phase. When we mutated T82 to aspartic acid, mimicking constant phosphorylation, cells no longer underwent differentiation. Conversely, changing T82 to alanine rendered Ste11-controlled transcription constitutive through the cell cycle, and allowed mating from $S$ phase with increased frequency. Thus, Cdk phosphorylation mediates periodic expression of Ste11 and its target genes, and we suggest this to be part of the mechanism restricting differentiation to $G_{1}$.
\end{abstract}

[Keywords: Cell cycle; differentiation; Cdk; Ste11; S. pombe]

Supplemental material is available at http://www.genesdev.org.

Received August 24, 2006; revised version accepted December 1, 2006.

Prior to the restriction point in late $\mathrm{G}_{1}$, eukaryotic cells can choose between alternative developmental strategies. Depending on the availability of nutrients, growth factors, and differentiation signals, $G_{1}$ cells can enter a quiescent $G_{0}$ state, commit to the mitotic cycle, or undergo differentiation. The level of cyclin-dependent kinase (Cdk) activity plays a critical role when a cell decides whether to grow mitotically or differentiate. In mammalian cells, high Cyclin D-Cdk4/6 activity under influence of growth-stimulatory signals favor entry into the mitotic cycle by causing phosphorylation of Rb-family pocket proteins, thereby releasing their repression over E2F transcription complexes, to stimulate transcription of genes required for $S$ phase (see Weinberg 1995). The importance of this Cdk-sensitive regulatory switch is illustrated by the fact that a majority of human cancer cells carry mutations in the Cyclin D/Rb pathway (Sherr 1996). Recently, the nonhomologous protein Whi5 was shown to carry out a function similar to Rb in Sac-

Present addresses: ${ }^{1}$ Institute of Exercise and Sport Sciences, University of Copenhagen, Universitetsparken 13, DK-2100 Copenhagen, Denmark; ${ }^{2}$ Niels Bohr Institute, University of Copenhagen, Blegdamsvej 17, DK2100 Copenhagen, Denmark.

${ }^{3}$ Corresponding author.

E-MAIL onigen@my.molbio.ku.dk; FAX 45-35322113.

Article is online at http://www.genesdev.org/cgi/doi/10.1101/gad.407107. charomyces cerevisiae, underscoring the universal logic of $\mathrm{G}_{1}$ phase control (Costanzo et al. 2004; de Bruin et al. 2004).

Several lines of evidence conversely suggest that low Cdk activity is a prerequisite for cellular differentiation. Mice lacking the Cdk inhibitors p21 and p57 are defective in muscle cell differentiation (Zhang et al. 1999), and several studies have implicated the hypophosphorylated $\mathrm{G}_{1}$ form of $\mathrm{Rb}$ as a cofactor in differentiation-specific transcription programs (Sellers et al. 1998; Thomas et al. 2001). Furthermore, Cdk activity can inhibit differentiation-specific transcription factors; for instance, Cyclin D-Cdk4 phosphorylation causes inactivation of the muscle-specific factor MEF2 (Lazaro et al. 2002). However, in general, little is known about the mechanisms that coordinate differentiation with the cell cycle.

The fission yeast Schizosaccharomyces pombe provides an attractive model system for studying the relationship between cell cycle progression and differentiation. The control mechanisms governing the mitotic cell cycle have been worked out in detail, and dynamic changes in the activity of a single cyclin-Cdk complex (Cdc13-Cdc2) can, in fact, drive the entire cycle (for review, see Stern and Nurse 1996). In early $G_{1}$, Cdk activity is low, but from START in late $\mathrm{G}_{1}$ (the yeast equivalent of the restriction point), a gradual increase in $\mathrm{Cdk}$ 
activity causes cells to commit to the mitotic cycle and ensures the correct ordering of $S$ and $M$ phases.

Fission yeast cells undergo sexual differentiation in response to nitrogen deprivation (for review, see Nielsen 2004; Yamamoto 2004). In this process, haploid P and $M$ cells first conjugate to form zygotes, which subsequently undergo meiosis and sporulation. Prior to mating, the cells arrest in $G_{1}$ under the influence of nutritional signaling and pheromone communication (Davey and Nielsen 1994; Imai and Yamamoto 1994; Kjaerulff et al. 2005). This is accomplished by down-regulation of Cdk activity, via increased cyclin proteolysis and induction of the Cdk inhibitor protein Rum1 (Stern and Nurse 1997, 1998). Hence, the signals inducing differentiation ensure that cells arrest in the pre-START window, from which mating occurs.

Starvation triggers differentiation by causing induction of the HMG-box transcription factor Ste11, which functions as a dose-dependent activator of the differentiation pathway (Sugimoto et al. 1991). Ste11 controls the expression of most proteins involved in the differentiation pathway, including components of the pheromone communication system (Nielsen 2004), and Mei2, the ultimate activator of meiosis (Watanabe et al. 1997), and in order to avoid unscheduled differentiation, the ste11 gene is tightly regulated at the transcriptional level. Furthermore, Ste11 can stimulate its own transcription (Kunitomo et al. 2000), and in order to avoid premature activation of a positive feedback loop, the protein must be kept inactive until conditions are appropriate for differentiation.

The starvation signal induces transcription of the ste11 gene by stimulating two different signaling pathways: one that acts by reducing cellular cAMP, thereby activating the Rts 2 transcription factor that directly controls ste11 transcription (Higuchi et al. 2002); and a second that triggers Atf1-dependent expression of the ste11 gene via activation of the Styl stress response pathway (Takeda et al. 1995). Moreover, starvation and pheromone signaling relieve the Ste11 protein from repression exerted by the Pat 1 protein kinase. Pat 1 phosphorylation creates a binding site for the 14-3-3 protein Rad24 (Kitamura et al. 2001), which excludes Ste11 from the nucleus, thus preventing autostimulation of the ste11 gene (Qin et al. 2003).

Forced expression of Ste11 will drive cells to differentiate irrespective of nutritional status (Sugimoto et al. 1991), but this still occurs from pre-START $\mathrm{G}_{1}$, suggesting the existence of a mechanism that prevents Stel1 from being active in the remaining part of the cell cycle. Consistent with this, the Ste11 target genes mat1-Mm and fus 1 can be induced by pheromone in $\mathrm{G}_{1}$-arrested cells but not in cells arrested at $S$ phase or in $G_{2}$ (Stern and Nurse 1998). Similarly, the meiotic activator gene mei3 is induced by starvation in diploid $\mathrm{G}_{1}$-arrested but not $\mathrm{G}_{2}$-arrested cells (Watanabe et al. 2001).

In this study, we explore the mechanism that prevents Ste 11 from being active outside $G_{1}$. We show that Ste 11 is a Cdk target that becomes phosphorylated on Thr 82 (T82). Unlike other Cdk targets at $\mathrm{G}_{1} / \mathrm{S}$, phosphorylation of Ste11 is not a prerequisite for ubiquitination and degradation; rather, it inhibits Ste11 DNA-binding activity. In $G_{1}$, when Cdc2-cyclin kinase activity is low, unphosphorylated Ste11 can bind its target sequences and, therefore, activate transcription of genes involved in differentiation. In the remaining part of the cell cycle, phosphorylation of Ste11 by Cdc2-cyclin complexes impairs its DNA-binding activity and, hence, transcription of Ste11-responsive genes.

\section{Results}

Ste11 is cell cycle regulated by Cdc2

Transcription of pheromone-induced Ste11 target genes is confined to $G_{1}$ (Stern and Nurse 1998), suggesting that Ste11 is only active as a transcription factor in this phase of the cell cycle. We therefore first monitored the accumulation of Ste11 protein in cells blocked at various cell cycle stages (Fig. 1A). This experiment showed that Ste11 was present in $\mathrm{G}_{1}$ (cdc10-V50 arrest) but decreased to very low levels in $S$ phase (HU treatment) and $G_{2}$ (cdc25-22 arrest).

To confirm that the level of Ste11 oscillates through the cell cycle, cdc25-22 cells were arrested in late $\mathrm{G}_{2}$ and synchronously released into mitosis (Fig. 1B). Ste11 was barely detectable at the cdc25-22 block point (Fig. 1B, middle panel), but some $30 \mathrm{~min}$ after release when cells were entering $G_{1}$, the level gradually increased, reaching a peak in $S$ phase. By 90 min, in early $G_{2}$, the level of Ste11 was down-regulated again and remained low through $G_{2}$ before reappearing in late $M$ phase. Hence, Ste11 is periodically expressed through the cell cycle peaking around S phase. Moreover, we note that dividing cells express Ste11 at a high level in S phase, whereas cells arrested in $S$ phase harbor a low level of the protein.

Next, we looked at Ste11-controlled transcription in the synchronized $c d c 25-22$ cell population. We choose the $m f m 2$ gene since it is expressed at a relatively high level in unstarved wild-type cells (Kjaerulff et al. 1994, 1997). As expected from the Ste 11 data, the mfm2 transcript level also fluctuated during the cell cycle. However, the expression peaked in $\mathrm{G}_{1}$, somewhat earlier than the protein, and declined as cells entered S phase (Fig. 1B, bottom panel), suggesting that Ste11 lost activity before it disappeared (see below). Thus, Ste11 is cell cycle regulated, and its activity peaks around START, where cells undergo differentiation. The same conclusion was reached by examining the levels of Ste11 protein and $\mathrm{mfm} 2$ transcript in wild-type cells synchronized by centrifugal elutriation (Supplementary Fig. S1).

The Cdk-inhibitor protein Rum 1 and the replicationinitiation protein Cdc18 are both down-regulated by Cdc2 phosphorylation at the $\mathrm{G}_{1}-\mathrm{S}$ transition (Jallepalli et al. 1997; Benito et al. 1998). We therefore investigated whether Cdc2 also had a role in down-regulation of Ste11. Temperature-sensitive $c d c 2-33$ mutant cells were shifted to the restrictive temperature, and samples were taken for Western blotting at $0,1,2$, and $4 \mathrm{~h}$ after the shift. Figure $1 \mathrm{C}$ shows that $\mathrm{Cdc} 2$, indeed, negatively regulates Ste11 as the protein level increased dramati- 
A

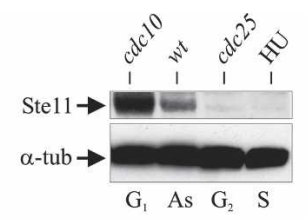

C
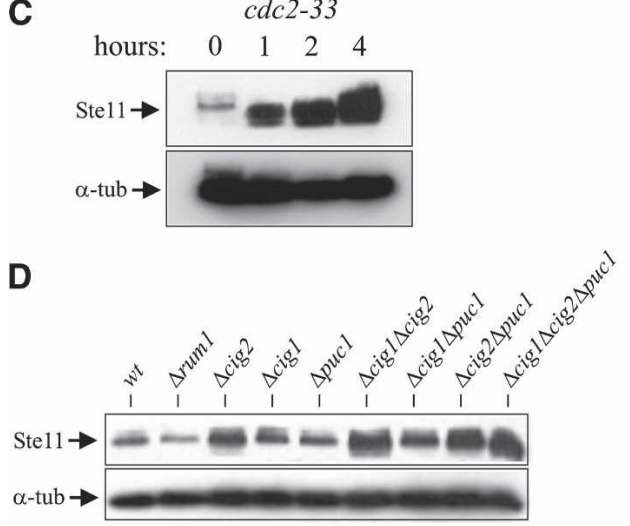

B
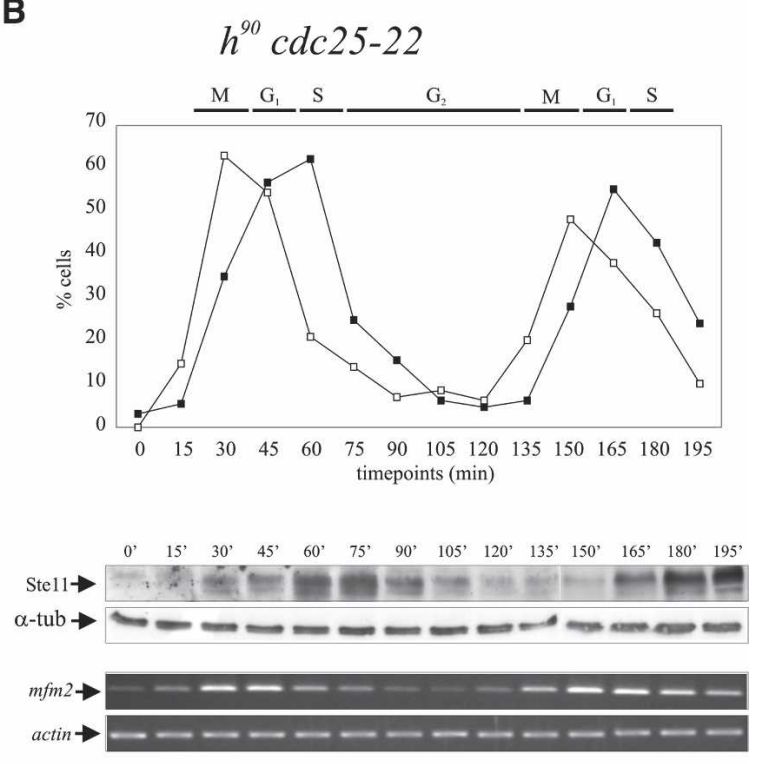

Figure 1. Periodicity of Ste11 protein levels and activity during the cell cycle. $(A)$ Western analysis of Ste11 protein from asynchronously (AS) growing cells and cells arrested in $\mathrm{G}_{1}, \mathrm{~S}$, and $\mathrm{G}_{2}$. cdc10-V50 and cdc25-22 strains were arrested in $\mathrm{G}_{1}$ and $\mathrm{G}_{2}$, respectively, by raising the temperature to $36^{\circ} \mathrm{C}$ for $4 \mathrm{~h}$. Wild-type cells were arrested in S phase by treatment with $20 \mathrm{mM}$ hydroxy-urea (HU) for $4 \mathrm{~h}$. ( $\alpha$-tub) Tubulin, which here serves as an internal control. (B) An exponentially growing $c d c 25-22$ strain was shifted from $25^{\circ} \mathrm{C}$ to $35.5^{\circ} \mathrm{C}$, and after $3.5 \mathrm{~h}$ of incubation the culture was released at the permissive temperature. After the release, the levels of Stel 1 protein and $\mathrm{mfm} 2$ transcript were followed by Western analysis (middle panel) and RT-PCR (bottom panel), respectively. (Top panel) The synchrony of the culture was followed by determining the percentage of cells in anaphase (open squares) and cells with a septum (closed squares). (C) Ste11 accumulates when Cdc2 is inactivated. Western analysis of Ste11 protein from a cdc2-33 strain incubated at $36^{\circ} \mathrm{C}$ for $0,1,2$, and $4 \mathrm{~h}$. (D) Ste11 levels are up-regulated in cig2 mutants. Western analysis of Ste11 protein from exponentially growing cultures of wild-type cells and rum1, cig2, cig1, puc1, cig1 cig2, cig1 puc1, cig2 puc1, and cig1 cig2 puc1 mutants.

cally after Cdc2 inactivation. Since $c d c 2-33$ cells are blocked in both $G_{1}$ and $G_{2}$ when incubated at the restrictive temperature (Nurse and Bissett 1981), the increase in protein levels could simply be a consequence of the cells accumulating in $\mathrm{G}_{1}$. However, we noticed that raising the temperature of $c d c 2-33$ caused a substantial fraction of Ste11 to migrate more rapidly (Fig. 1C), suggesting a reduced phosphorylation of the protein and hence implying a more direct role of Cdc2 in Ste11 regulation.

In fission yeast, Cig2 is the major cyclin activating Cdc2 kinase activity at the $\mathrm{G}_{1} / \mathrm{S}$ transition (Martin-Castellanos and Moreno 1996; Mondesert et al. 1996). Consistent with Cdc2 being a negative regulator of Ste11, we found that deletion of cig2 caused a significant increase in the Ste11 level in asynchronously growing cells (Fig. 1D). Deletion of the cig1 and puc1 genes, encoding two minor fission yeast $G_{1}$ cyclins, only caused a minor increase in Ste11 levels. However, we observed an additive effect on Ste11 accumulation when we combined deletions of cig1 and/or puc1 with the cig2 deletion (Fig. 1D). These results indicate that the increase in Cdc2 activity at the $G_{1} / S$ transition, in particular Cig2-associated activity, plays a major role in Ste11 down-regulation.

\section{Ste11 is phosphorylated at T82 by Cdc2}

Although these genetic experiments suggest that Cdc2 inhibits Ste11, they do not discriminate between direct and indirect effects. We therefore investigated whether Ste11 is a direct target for Cdc2 phosphorylation. We noticed that Ste11 contains a single TPKK consensus site for Cdk phosphorylation situated immediately C-terminal to its DNA-binding HMG domain, with the putative phospho-acceptor being at T82 (Fig. 2A,). To determine if Ste11 is phosphorylated at T82 in vivo, we overexpressed a truncated, glutathione-S-transferase (GST) fusion of the transcription factor (pREP3X-GST-Ste $11_{1-113}$ ) in mitotically growing cells. Ste $11_{1-113}$ was purified by immunoprecipitation and resolved by SDS-PAGE. The protein was in-gel digested with trypsin and analyzed by MALDI-TOF mass fingerprinting and MALDI-TOF/TOF peptide sequencing. A single phosphopeptide was detected with the sequence HMLENPEYKYTPK /residues 72-84), supporting the idea that Ste11 is phosphorylated at T82 (Fig. 2A; Supplementary Fig. S2).

To determine whether Cdc2 is capable of phosphorylating Ste11 T82 in vitro, we immunoprecipitated Cdc2 and Cig2 from vegetatively growing cells and performed kinase assays using an Escherichia coli-expressed GSTtagged version of Ste $11_{1-113}$ (GST-Ste $11_{1-113}$ ) as a substrate. We found that both Cdc2 and Cig2 immunocomplexes phosphorylated GST-Ste $11_{1-113}$ as efficiently as they phosphorylated histone H1 (Fig. 2B). Importantly, a GST fusion protein mutated in the presumed phosphoacceptor T82 (GST-Ste11 ${ }^{\mathrm{T} 82 \mathrm{~A}}$ ) was a very poor substrate for the Cdc2 kinase. We subjected in vitro phosphory- 
A

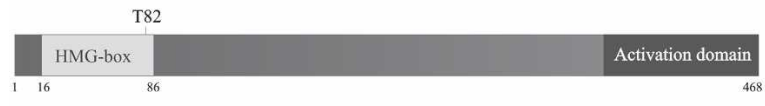

Putative Cdk phosphorylation site: TPKK

Phosphopeptide identified in vivo and in vitro:

$\mathrm{H}_{72}$ MLENPEYKYTPK $_{84}(1729 / 1745 \mathrm{Da})$

B

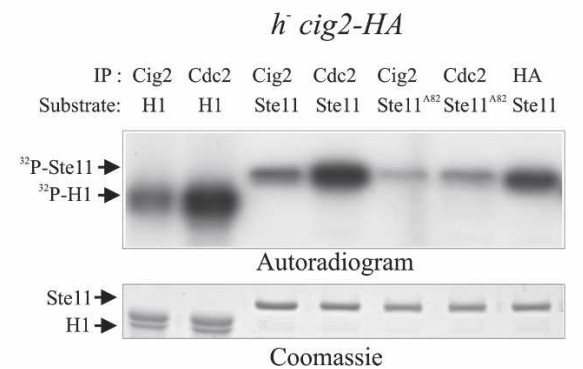

C

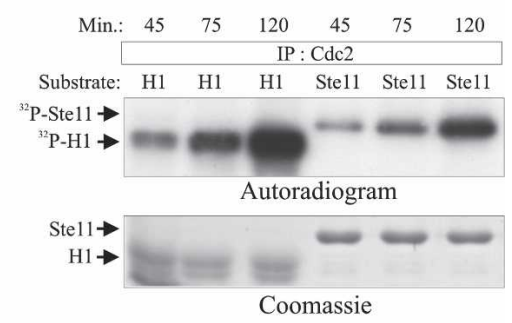

D

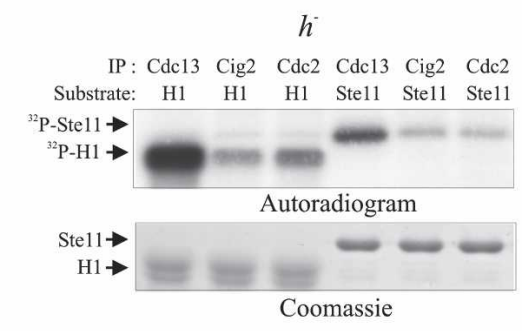

Figure 2. Ste11 is phosphorylated by Cdc2 in vitro and in vivo. (A) Schematic representation of Ste11 showing T82 that occurs in a Cdk phosphorylation consensus sequence, S/T-P-X-K/R. The 1729-kDa phosphopeptide identified from in vitro and in vivo phosphorylated Ste11 by mass spectrometry is shown below (for details, see Supplemental Material). $(B-D)$ In vitro kinase assays. $(B) h^{-}$ cig2-HA cells were grown to mid-exponential phase in minimal medium. Protein extracts were prepared and immunoprecipitated with anti-Cdc2, anti-Cig2, and anti-HA antibodies. Protein kinase activities were measured using histone H1 (H1), wild-type Ste11 ${ }_{1-113}$ (Ste11), and Ste $11^{\mathrm{T} 82 \mathrm{~A}}{ }_{1-113}\left(\mathrm{Ste} 11^{\mathrm{T} 82 \mathrm{~A}}\right)$ as substrates. Kinase assays were carried out for $15 \mathrm{~min}$ at $30^{\circ} \mathrm{C}$, and the samples were separated by SDS-PAGE, followed by autoradiography (top panel) or Coomassie staining (bottom panel). (C) Samples from time points 45, 75, and $120 \mathrm{~min}$ from the synchronized cdc25 cells (see Fig. 1B) were analyzed for Cdc2 activity. Protein extracts were immunoprecipitated with anti-Cdc2 antibodies and kinase activities were measured as described above using histone H1 and wild-type Ste11 $1_{1-113}$ as substrates. $(D) h^{-}$cells were grown to mid-exponential phase in minimal medium. Protein extracts were immunoprecipitated with anti-Cdc13, anti-Cdc2, and anti-Cig2 antibodies. Kinase activities were measured as described above using histone H1 and wild-type Ste $11_{1-113}$ as substrates.

lated GST-Ste $11_{1-113}$ and GST-Ste $11^{\text {T82A }}{ }_{1-113}$ to MALDITOF mass fingerprinting. The peptide spanning residues 72-84 was phosphorylated in GST-Ste $11_{1-113}$, but not in GST-Ste $11^{\text {T82A }}{ }_{1-113}$ (Supplementary Fig. S2). Finally, we found that GST-Ste $11_{1-113}$ purified from $S$. pombe cells reacted with a phosphor-threonine-specific antibody, and that this signal was strongly reduced upon inactivation of Cdc2 (Supplementary Fig. S2). Collectively, these results show that Ste11 is phosphorylated by Cdc2 at T82 in vivo.

Cig2-Cdc2 activity rapidly declines after peaking at the $\mathrm{G}_{1} / \mathrm{S}$ transition (Martin-Castellanos and Moreno 1996; Yamano et al. 2000) and is replaced by Cdc13Cdc2, which is the predominant Cdk activity in $\mathrm{G}_{2}$ and M phases (Booher et al. 1989; Moreno et al. 1989). To test if this complex was also involved in repressing Ste11, we compared the Ste11-phosphorylating Cdc2 kinase activity in early $G_{1}$, in $S$ phase, and in late $G_{2}$ using cells from the cdc25-22 block-release experiment described in Figure $1 \mathrm{~B}$ (time points 45,75 , and $120 \mathrm{~min}$ ). Cdc2 was immunoprecipitated from these samples, and the collected immune complexes were mixed with recombinant GSTSte $11_{113}$. As shown in Figure 2C, high levels of Ste11phosphorylating activity were present in all three samples including that from $\mathrm{G}_{2}$ cells $(120 \mathrm{~min})$. We confirmed that $\mathrm{Cdc13}$ immune complexes had the ability to phosphorylate Ste11 in vitro (Fig. 2D). These results demonstrate that Ste11 is an excellent substrate for Cdc2 kinase in vitro and imply that both Cig2- and Cdc13associated Cdc2 are responsible for repressing Ste11 outside $\mathrm{G}_{1}$.

\section{Cdk phosphorylation site mutations affect sexual differentiation}

If Cdc2 down-regulates Ste11 by phosphorylating T82, we reasoned that mutations in this residue could influence the ability of cells to undergo sexual differentiation. To investigate this, we first constructed an "inactive" version of the protein where T82 was replaced with aspartic acid to mimic constant phosphorylation. When this ste $11^{T 82 D}$ allele was expressed from the authentic ste11 locus in homothallic $h^{90}$ cells, we observed that the cells became severely impaired in their ability to undergo sexual development (Fig. 3; Table 1). When cultivated on solid minimal medium, very few cells entered meiosis, as revealed by iodine staining (Fig. 3A) and microscopy (Fig. 3B). We also measured the effect of ste $11^{T 82 D}$ on conjugation and sporulation in nitrogenstarved liquid cultures (Table 1); no zygotes were formed after $22 \mathrm{~h}$ of starvation, when $~ 55 \%$ of the wild-type cells had mated. Western analysis revealed that ste $11^{T 82 D}$ 
A

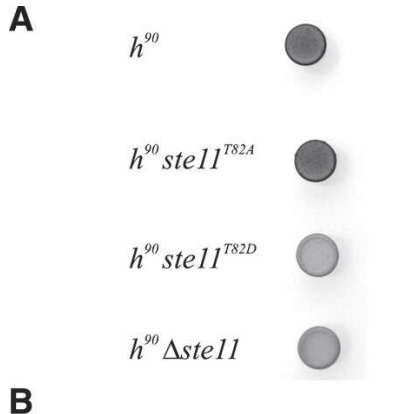

B

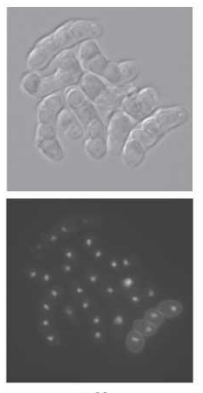

$h^{90}$

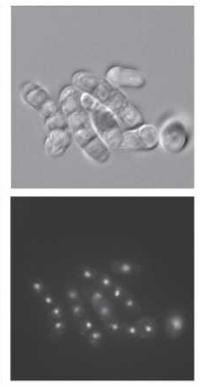

$h^{90}$ ste $^{\text {T82A }}{ }^{\text {T8A }}$

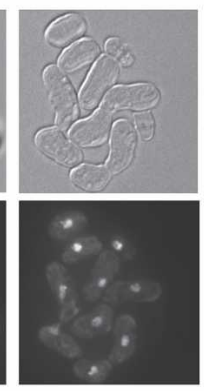

$h^{90}$ ste $11^{T 82 D}$
C

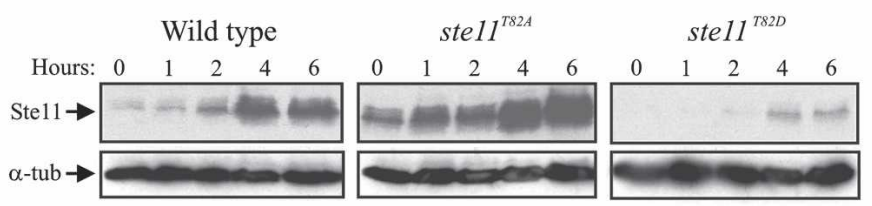

D
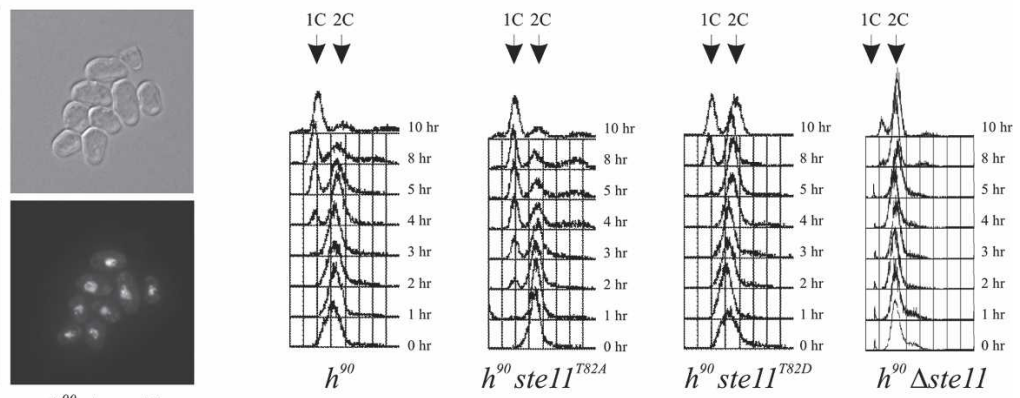

$h^{90} \Delta$ stell

Figure 3. Characterization of ste $11^{T 82}$ mutants in fission yeast. $(A, B)$ ste $11^{T 82 D}$ mutants are semisterile. $(A)$ Iodine staining of cells plated on sporulation medium. Homothallic wild-type, ste $11^{T 82 A}$, ste $11^{T 82 D}$, and $\Delta$ ste 11 strains were plated on MSA and incubated for $48 \mathrm{~h}$ prior to iodine staining. The same cells were fixed and micrographed. (B, bottom panel) Cells stained with DAPI. DIC images of the same cells are shown above. $(C)$ T82 mutations affect the level of Ste11 protein in vegetatively growing cells and in nitrogenstarved cells. Western analysis of Ste11 protein from wild-type, ste $11^{T 82 A}$, and ste $11^{T 82 D}$ strains nitrogen-starved for $0,1,2,4$, and 6 h. $(D)$ The same strains together with a $\Delta$ ste 11 strain were nitrogen-starved for $0,1,2,3,4,5,8$, and $10 \mathrm{~h}$, and the DNA content of the cells was analyzed by flow cytometry.

cells produced scarce amounts of Ste11 protein, explaining their semisterile phenotype (Fig. 3C). Moreover, we found that Ste11 target genes such as $\mathrm{mfm} 2$ and ste11 itself were only weakly expressed in ste $11^{T 82 D}$ cells (Supplementary Fig. S3). Hence, the T82D substitution causes a severe down-regulation of the Ste11 protein level, presumably by mimicking the effect of Cdc2 phosphorylation.

We next asked whether we also could make a hyperactive version of Ste11 by changing T82 to nonphosphorylatable alanine. Interestingly, cells carrying this ste $11^{T 82 A}$ allele in the genome had highly elevated levels of Ste11 when cultivated both in rich and nitrogen-depleted medium (Fig. 3C). Consequently, the expression level of ste11 target genes (including ste11 itself) was higher than in wild-type cells (Supplementary Fig. S3). However, the ste $11^{T 82 A}$ cells still required nitrogen starvation in order to undergo mating (Table 1), suggesting that nutritional control over Ste11 expression was still functional.

We therefore looked for other phenotypic consequences of the ste $11^{T 82 A}$ mutation. Prior to mating, fission yeast cells arrest in $G_{1}$ in response to nitrogen limitation and pheromone signaling (Davey and Nielsen 1994; Imai and Yamamoto 1994), and this process requires Ste11 (Fig. 3D; Kjaerulff et al. 2005). By flow cytometry we compared the kinetics of $\mathrm{G}_{1}$ arrest when homothallic cells were transferred to nitrogen-free me- dium (Fig. 3D; Supplementary Fig. S4). Wild-type cells on average underwent two residual divisions and started to accumulate in $\mathrm{G}_{1} \sim 3 \mathrm{~h}$ after the nutritional shift. In the ste $11^{T 82 A}$ strain, however, $\mathrm{G}_{1}$ cells appeared already after $<2 \mathrm{~h}$ of starvation, suggesting that the increased Ste11 level made a fraction of the cells arrest already in the first cell cycle. Hence, ste $11^{T 82 A}$ represents an activated allele of ste11. In ste $11^{T 82 D}$ cells, the $\mathrm{G}_{1}$ arrest was both delayed and less pronounced (Fig. 3D); $\mathrm{G}_{1}$ cells only started accumulating after $>5 \mathrm{~h}$ of starvation, and after $10 \mathrm{~h}$, only $50 \%$ of the cell population was in $\mathrm{G}_{1}$. How-

Table 1. Effect of mutations in ste11 on mating and meiosis

\begin{tabular}{lcccccc}
\hline & \multicolumn{5}{c}{ \% of sporulation } \\
\cline { 2 - 7 } Strain & $0 \mathrm{~h}$ & $2 \mathrm{~h}$ & $4 \mathrm{~h}$ & $6 \mathrm{~h}$ & $8 \mathrm{~h}$ & $22 \mathrm{~h}$ \\
\hline$h^{90}$ & 0.0 & 0.0 & 1.2 & 5.6 & 20.8 & 55.7 \\
$h^{90}$ ste $11^{T 82 A}$ & 0.0 & 0.0 & $4.1^{\mathrm{b}}$ & 7.3 & 23.4 & 58.5 \\
$h^{90}$ ste $11^{T 82 D}$ & 0.0 & 0.0 & $0.0^{\mathrm{b}}$ & $0.0^{\mathrm{b}}$ & $0.0^{\mathrm{b}}$ & $0.0^{\mathrm{b}}$ \\
\hline
\end{tabular}

${ }^{\mathrm{a} C}$ Cultures of Eg640, Eg1105, and Eg1115 were grown in MSL to a density of $2.5 \times 10^{6}$ cells $/ \mathrm{mL}$, and then shifted to MSL without nitrogen. Samples were taken at the indicated times, and the percentage of sporulation was estimated by microscopic examination as described in Materials and Methods. Values represent means of three separate trials.

${ }^{\mathrm{b}}$ Sporulation is significantly different from that of wild-type $h^{90}$ cells $(P<0.05$; tested by Student's $t$-test $)$. 
ever, the arrest still occurred faster than in cells without the ste11 gene (Fig. 3D). In conclusion, Ste11 T82 can be manipulated to both hypo- and hyperactivate the protein, consistent with Cdc2 phosphorylation of this residue exerting a negative regulatory effect.

\section{Ste11 is polyubiquitinated independently} of T82 status

How then does Cdc2 cause down-regulation of Ste11? We first speculated that phosphorylation of T82 may trigger SCF-mediated polyubiquitination of Ste11 and subsequent degradation by the $26 \mathrm{~S}$ proteasome, similar to the regulation reported for Rum 1 and Cdc18 (Jallepalli et al. 1997; Benito et al. 1998). In support of this idea, high-molecular-weight (presumably polyubiquitinated) forms of Ste11 have been reported to accumulate in a 26S proteasome mutant (Kitamura et al. 2001). We confirmed that Ste11 indeed is polyubiquitinated by expressing a His $_{6}$-tagged version of ubiquitin in the temperature-sensitive proteasome mutant mts3-1 (Gordon et al. 1996). We purified His $_{6}$-tagged ubiquitin-containing complexes and monitored for the presence of Ste 11 protein by Western blotting. High-molecular-weight Ste11-containing forms were detected when the cells were grown at the restrictive temperature (Fig. 4A), but not at the permissive temperature (data not shown). Consistent with this, we observed that Ste11 became stabilized when mts3-1 cells were incubated at the restrictive temperature (Fig. 4B). Surprisingly, however, we could readily detect polyubiquitinated Ste11 independently of T82 status (Fig. 4A), suggesting that phosphorylation of this residue is not a prerequisite for polyubiquitination and degradation.

We therefore compared the stability of wild-type Ste11, Ste $11^{\mathrm{T} 82 \mathrm{~A}}$, and Ste $11^{\mathrm{T} 82 \mathrm{D}}$. The three proteins were expressed from the repressible nmt1 promoter (pREP41X), and the degradation kinetics was monitored after shut-off of transcription in the presence of cycloheximide to block de novo protein synthesis. Wild-type Ste11, Ste $11^{\mathrm{T} 82 \mathrm{~A}}$, and Ste $11^{\mathrm{T} 82 \mathrm{D}}$ were all rapidly degraded with a comparable half-life of $<20 \mathrm{~min}$ (Fig. 4C), suggesting that their very different steady-state levels are not due to different stabilities. We confirmed that the stability of Ste11 was approximately the same in cells arrested in $G_{1}$, in $S$ phase, or in $G_{2}$ (data not shown), consistent with the drop in Ste11 level observed at $S$ phase not being caused by increased turnover. Finally, we found no evidence for involvement of the SCF or APC E3 ubiquitin ligase complexes in down-regulation of Ste11 (Supplementary Fig. S5). In summary, we conclude that Ste11 is a polyubiquitinated, unstable protein and that phosphorylation of T82 does not seem to influence its stability.

\section{Cdk phosphorylation impairs DNA-binding activity of Ste11}

We therefore considered other explanations for the inhibitory effect of Ste11 T82 phosphorylation. We previously modeled the binding of Ste11 to its cognate DNA sequence (van Beest et al. 2000). According to this model, T82 is in close contact with the phosphate backbone of the DNA helix, indicating that phosphorylation of this
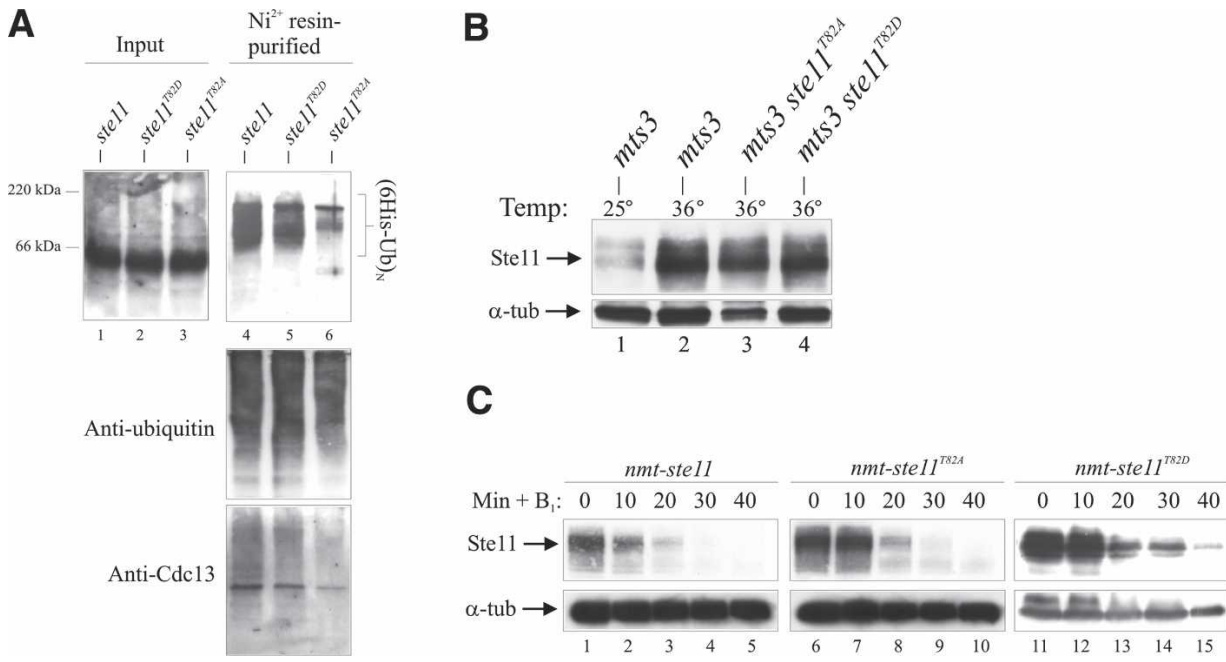

Figure 4. Ste11 is polylubiquitinated independently of T82 phosphorylation. $(A) m t s 3-1, m t s 3-1$ ste $11^{T 82 A}$, and $m t s 3-1$ ste $11^{T 82 D}$ strains were grown at $25^{\circ} \mathrm{C}$ and shifted to $36^{\circ} \mathrm{C}$ for $4 \mathrm{~h}$. The level of Stell was determined by Western analysis. $(B)$ His $6^{- \text {ubiquitin was }}$ expressed from the $n m t 1$ promoter in the same cells for $18 \mathrm{~h}$ at $25^{\circ} \mathrm{C}$ followed by $4 \mathrm{~h}$ at $36^{\circ} \mathrm{C}$. (Left panel) Cell extracts were prepared from these cultures and analyzed for the presence of Ste11 by Western blotting (input) and subjected to $\mathrm{Ni}^{2+}{ }_{-} \mathrm{NTA}$ chromatography. Purified ubiquitin conjugates were analyzed by Western blotting using anti-Stel1 (top panel), anti-ubiquitin (middle panel), and anti-Cdc13 (bottom panel) antibodies. Western blot using anti-ubiquitin here serves as a loading control. $(C)$ The half-life of wild-type Ste11, Ste11 $1^{\mathrm{T} 82 \mathrm{~A}}$, and Ste $11^{\mathrm{T} 82 \mathrm{D}}$ is approximately the same. $\Delta$ ste 11 cells expressing wild-type Ste11 (lanes 1-5), Ste11 ${ }^{\mathrm{T} 82 \mathrm{~A}}($ lanes 6-10), and Ste $11^{\mathrm{T} 82 \mathrm{D}}$ (lanes 11-15) from the nmt1 promoter were grown in the absence of thiamine. At time point 0 , thiamine $(6 \mu \mathrm{M})$ and cycloheximide $(100 \mu \mathrm{g} / \mathrm{mL})$ were added, and samples were taken every $10 \mathrm{~min}$ to determine Ste11 protein levels by Western blotting. 
residue may impair DNA binding. Since the Ste11 protein is autoregulated (Kunitomo et al. 2000) and is intrinsically unstable (this study), such a mechanism would cause disappearance of Ste11 when Cdc2 activity increases as cells enter $\mathrm{S}$ phase. Supporting this idea, we initially observed that recombinant Ste $11^{\text {T82D }}$ bound its target sequence with a two- to threefold lower affinity than wild-type Ste11 or Ste11 ${ }^{\text {T82A }}$ (Table 2; Supplementary Fig. S6). Moreover, upon binding, Ste11 ${ }^{\mathrm{T} 82 \mathrm{D}}$ caused a less severe bending of the DNA helix than wild-type Ste11 or Ste11 ${ }^{\mathrm{T} 82 \mathrm{~A}}$ (Supplementary Fig. S6), consistent with this substitution affecting binding.

We therefore used electrophoretic mobility shift analysis (EMSA) to monitor the effect of Cdc2 phosphorylation on Ste11 DNA binding. Interestingly, treatment with Cdc2 immune complexes inhibited the binding of wild-type Ste11 to its target sequence (Fig. 5A), but had no effect on the binding activity of Ste11 ${ }^{\text {T82A }}$ (Fig. 5B).

Human Cdk1 is a functional ortholog of the fission yeast Cdc2 (Lee and Nurse 1987), and we found that purified recombinant human Cdk1-Cyclin B complex phosphorylated Ste11 in a T82-dependent manner (Fig. $5 \mathrm{E})$. In the presence of ATP, $2.5 \mathrm{ng}$ of Cdk1-Cyclin B completely abolished the DNA-binding activity of 100 ng of Ste11 (Fig. 5A). Similar to the fission yeast kinase, human Cdk1 had no effect on the binding activity of Ste11 ${ }^{\text {T82A }}$ (Fig. 5C). For technical reasons the subsequent control experiments were all performed with human Cdk1-Cyclin B. Cdk1 impaired the binding activity of Ste11 in an ATP-dependent manner: In the absence of ATP or in the presence of the nonhydrolyzable ATP analog, AMP-PNP, no reduction of Ste11-binding activity was observed (Fig. 5C,D). Finally, we showed that treatment of a Cdk1-phosphorylated Ste11 sample with purified Protein Phosphatase 1 restored most of its DNAbinding activity (Fig. 5D). These results demonstrate that Cdk1 phosphorylates Ste11 with a concomitant loss of DNA-binding ability.

Intriguingly, when we incubated Ste11 with human Cdk1-Cyclin B, we occasionally observed two extra shifted complexes with faster mobility (Fig. 5C,D). Supershift experiments suggested that both bands contained Ste11 but not Cdk1-Cyclin B (Fig. 5C). We do not

Table 2. Dissociation constants of Ste11 proteins

\begin{tabular}{lc}
\hline Ste11 & $K_{d}(\mathrm{M})^{\mathrm{a}}$ \\
\hline Wild type & $1.7 \times 10^{-8} \pm 0.3 \times 10^{-8}$ \\
T82A & $1.5 \times 10^{-8} \pm 0.2 \times 10^{-8}$ \\
T82D & $3.8 \times 10^{-8} \pm 0.8 \times 10^{-8 \mathrm{~b}}$ \\
\hline
\end{tabular}

$\overline{{ }^{a} \text { Recombinant Ste11 proteins were added in different concen- }}$ trations to $1 \mathrm{nM}$ of a TR-box-containing probe, and the samples were incubated until the binding reactions were at equilibrium. Free and bound DNA was separated by EMSA, and $K_{d}$ was determined as the concentration of Ste 11 protein required to bind $50 \%$ of the probe. Values represent means and standard deviations (SD) of three separate trials.

${ }^{b}$ Binding is significantly different from that of wild-type Ste11 $(P<0.05$; tested by Student's $t$-test $)$. know the nature of these complexes, but they appear not to be due to proteolysis of Ste11 (S. Kjærulff and O. Nielsen, unpubl.).

\section{Ste11 T82 phosphorylation plays a role in cell cycle regulation of differentiation}

If Cdc2 phosphorylation of T82 is responsible for Ste11 down-regulation upon $G_{1}$ exit, then the T82A mutation is expected to abolish cell cycle regulation of Ste11. To test this prediction, we measured the protein levels in ste $11^{T 82 A}$ cells released from a $c d c 25-22$ block (Fig. 6). In $\mathrm{G}_{2}$-arrested cells, Ste11 ${ }^{\mathrm{T} 82 \mathrm{~A}}$ was, like the wild-type protein, expressed at a low level. On release from $G_{2}$, Ste $11^{\mathrm{T} 82 \mathrm{~A}}$ rapidly accumulated, and, interestingly, the protein level remained high for the following $180 \mathrm{~min}$. Thus, as opposed to wild-type Ste11 (Fig. 1B), the Ste $11^{\text {T82A }}$ protein was not down-regulated at $S$ phase.

We next asked whether the Ste $11^{\mathrm{T} 82 \mathrm{~A}}$ protein produced in $S$ phase and $G_{2}$ was active, by measuring the expression of $\mathrm{mfm} 2$ in the synchronized cdc25-22 ste $11^{T 82 A}$ cell populations (Fig. 6 , bottom panel). Remarkable, $\mathrm{mfm} 2$ was now more or less constitutively expressed through the cell cycle. Thus, when phosphorylation of T82 is prevented, the periodical expression of Ste11 and its target genes becomes severely compromised.

We finally tested whether the ste $11^{T 82 A}$ mutation would allow differentiation from other phases of the cell cycle. In order to do this, we compared the ability of ste $11^{T 82 A}$ and ste $11^{+}$cells to mate at various $c d c$ mutant block points (Nurse and Bissett 1981). After $4 \mathrm{~h}$ of arrest at $36^{\circ} \mathrm{C}$, the cells were shifted to $33^{\circ} \mathrm{C}$ and challenged overnight with a mating partner. The cell mix was then plated to score the number of diploids formed (Table 3). When cells were arrested in S phase at the $c$ dc22-M45 block point, ste $11^{T 82 A}$ cells mated with a three- to fourfold higher frequency than ste $11^{+}$cells. However, at the cdc25-25 block in $\mathrm{G}_{2}$, ste $11^{T 82 A}$ cells only mated moderately more efficiently than wild type. Hence, in ste $11^{T 82 A}$ cells, constitutive Ste11-controlled transcription is clearly not sufficient to allow cells to mate efficiently from $\mathrm{G}_{2}$.

\section{Discussion}

\section{Coordination of differentiation with the cell cycle}

The eukaryotic cell cycle can be considered as a series of oscillations between intervals of low and high Cdk activity. A gradual increase in Cdk activity from its low $\mathrm{G}_{1}$ level is required for the correct assembly and activation of replication origins at $S$ phase. In $G_{2}$, the Cdk activity increases further, and is important for preventing re-replication of the genome, until it reaches a threshold that activates mitosis. Finally, when cells exit mitosis, Cdk activity is reset back to its low $G_{1}$ level.

In this study we have provided evidence that in fission yeast this oscillator also ensures that differentiation oc- 
Kjærulff et al.

A

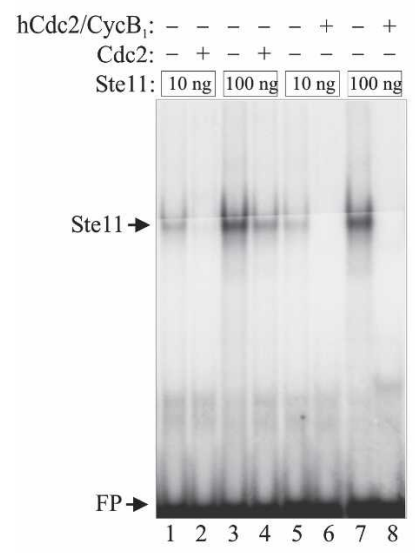

D Ppl: - _ _ _ + AMP-PNP: - --++-ATP: -+-+-+-+ $\mathrm{hCdc} 2 / \mathrm{CycB}_{1}:--++++++$ Ste11: ++++++--

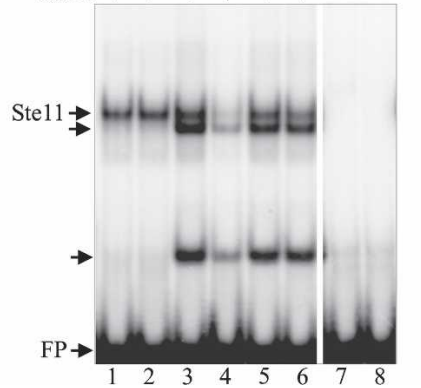

B

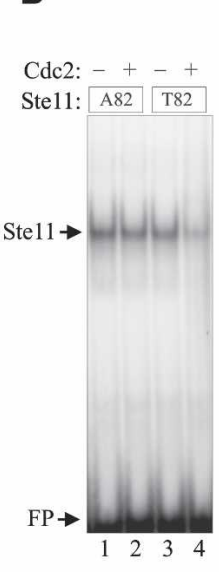

E
C

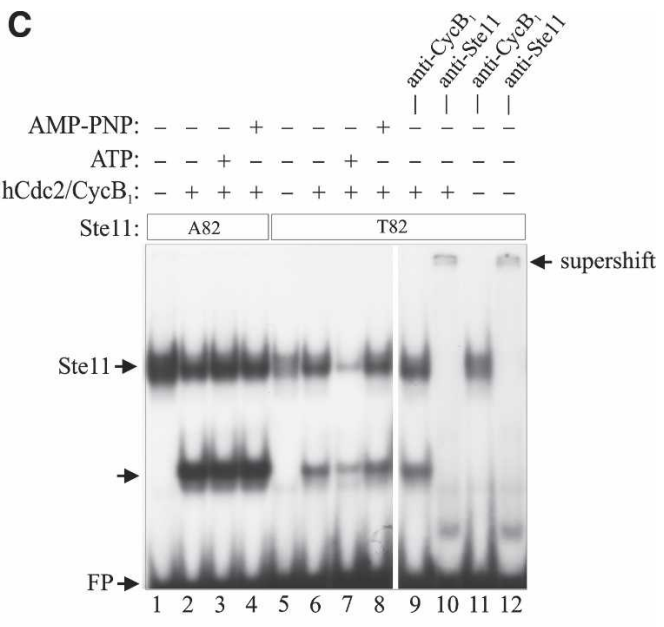

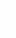

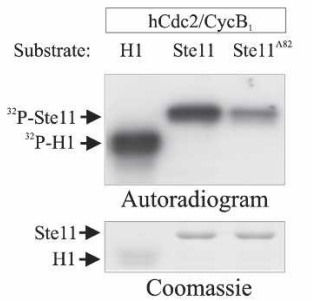

Figure 5. Cdc2 inhibits the DNA-binding activity of bacterially produced Ste11. (A) Purified GST-Ste11 (10-100 ng) was either directly assayed by EMSA for DNA-binding activity or was first incubated with either fission yeast Cdc2 immune complexes or with $2.5 \mathrm{ng}$ (50 U) of recombinant human Cdc2-Cyclin $\mathrm{B}_{1}$ complex (New England Biolabs) in the presence of ATP. (B) Ten nanograms of GST-Ste11 and GST-Ste $11^{\mathrm{T} 82 \mathrm{~A}}$ were either directly assayed by EMSA for DNA-binding activity or were first incubated with ATP and Cdc2 immunoprecipitated from fission yeast cells. (C) Twenty-five nanograms of GST-Ste11 and GST-Ste $11^{\mathrm{T} 82 \mathrm{~A}}$ were either directly assayed by EMSA for DNA-binding activity or were first incubated with $0.5 \mathrm{ng}$ of human Cdc2-Cyclin $\mathrm{B}_{1}$ complex in the presence or the absence of ATP or AMP-PNP. In addition, lanes $9+11$ and lanes $10+12$ contained anti-Cyclin $\mathrm{B}_{1}$ and anti-Ste11 antibodies, respectively. $(D)$ In a similar assay, the effect of adding Protein Phosphatase 1 (Pp1) to Cdc2-Cyclin $\mathrm{B}_{1}$-phosphorylated GST-Ste11 was examined (cf. lanes 4 and 6). In addition the DNA-binding activity of Cdc2-Cyclin $B_{1}$ was assayed in the absence of GST-Ste11 (lanes $7+8) .(E)$ In vitro kinase assay. Protein kinase activities of recombinant human Cdc2-Cyclin $\mathrm{B}_{1}$ were measured using histone $\mathrm{H} 1$ (H1), wild-type Ste $11_{1-113}(\mathrm{Ste} 11)$, and Ste $11^{\mathrm{T} 82 \mathrm{~A}}{ }_{1-113}\left(\mathrm{Ste} 11^{\mathrm{T} 82 \mathrm{~A}}\right)$ as substrates. Kinase assays were carried out for $15 \mathrm{~min}$ at $30^{\circ} \mathrm{C}$, and the samples were separated by SDS-PAGE, followed by autoradiography and Coomassie staining.

curs from the $\mathrm{G}_{1}$ phase. Ste11, the key transcription factor required for sexual differentiation, is only active in $\mathrm{G}_{1}$; in the remaining part of the cell cycle its activity is inhibited by Cdk phosphorylation. When cells enter S phase, the increase in Cdk activity causes phosphorylation of Ste11 on T82, which inhibits binding of the transcription factor to its target genes. Since the ste 11 gene is autoregulated, this prevents de novo expression of Ste11 protein and other Ste11 targets until the next $\mathrm{G}_{1}$. Furthermore, because the protein is highly unstable, it will rapidly disappear once synthesis is blocked. Our observation that Ste11 lost its activity as a transcription factor before it physically disappeared when synchronous cells went from $G_{1}$ to $S$ phase is consistent with this model. Similarly, cells arrested by HU had a much lower level of
Ste11 in $S$ phase than vegetatively growing cells, presumably because the protein here had time to decay under conditions in which Ste11-controlled transcription was blocked by phosphorylation.

Ste11 is polyubiquitinated and degraded by the $26 \mathrm{~S}$ proteasome, but unlike, for example, cyclins, the fluctuations in protein levels observed through the cell cycle are not brought about by changes in stability. Rather, Ste11 cell cycle regulation is caused by constitutive instability in combination with a Cdk-sensitive autocatalytic switch (see Fig. 7).

The importance of T82 phosphorylation for cell cycle regulation of Ste11 is particularly evident from our finding that $\mathrm{G}_{1}$-specific expression of Ste11-controlled transcription was almost lost in the ste $11^{T 82 A}$ mutant. Fur- 


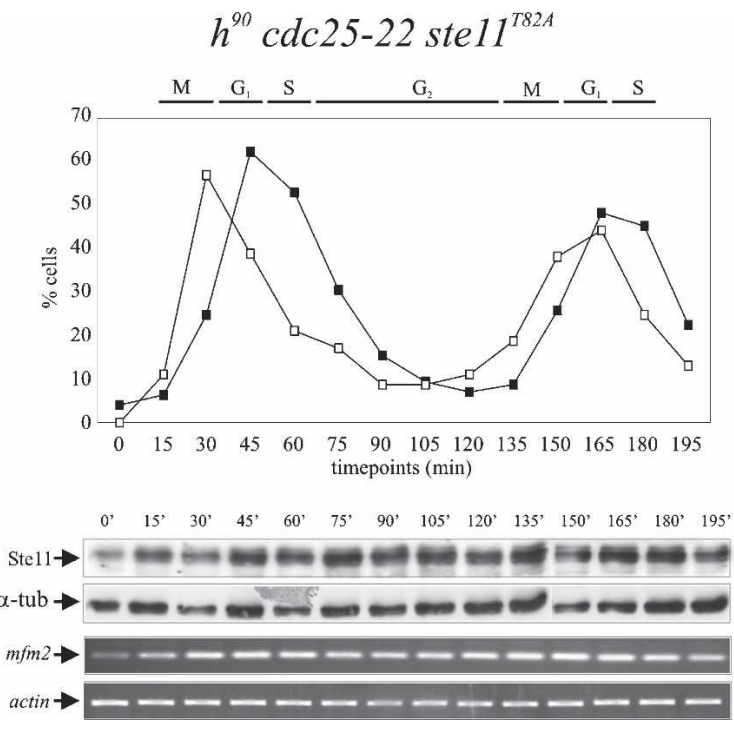

Figure 6. In ste $11^{T 82 A}$ mutants, the periodicity in expression of Ste11 and $m f m 2$ is lost. An exponentially growing $c d c 25-22$ ste $11^{T 82 A}$ strain was shifted from $25^{\circ} \mathrm{C}$ to $35.5^{\circ} \mathrm{C}$, and after 3.5 $\mathrm{h}$ of incubation, the culture was released at the permissive temperature. After the release, the levels of Ste 11 protein and $\mathrm{mfm} 2$ transcript were followed by Western analysis (middle panel) and RT-PCR (bottom panel), respectively. (Top panel) The synchrony of the culture was followed by determining the percentage of cells in anaphase (open squares) and cells with a septum (closed squares).

thermore, in these cells, START control over differentiation was compromised, opening up for differentiation from later stages of the cell cycle.

Transcription still fluctuates somewhat in the T82A mutant, suggesting that other mechanisms contribute to down-regulation of Ste11 outside $\mathrm{G}_{1}$. This is also reflected in the observation that the Ste $11^{\mathrm{T} 82 \mathrm{~A}}$ protein was eventually down-regulated in cdc25-22 arrested cells. We do not know these mechanisms, but when the $c d c 2$ 33 allele was inactivated, we saw several faster migrating Ste11 bands, suggesting that the protein is phosphorylated at other sites than T82. The ste 11 protein contains a total of 11 SP or TP sites, and perhaps Cdc2 phosphorylation of some of these somehow influences the protein level in vivo. Furthermore, the eventual down-regulation of Ste11 in cdc25-22 arrested ste $11^{T 82 A}$ cells provides an explanation for their relatively poor mating efficiency. In budding yeast, Cdk activity inhibits the pheromone response pathway downstream from the receptors, presumably by phosphorylating the Ste20 protein (Oehlen and Cross 1998), and Cdk may similarly inhibit differentiation at another level than Ste11 in fission yeast. However, given the dramatic consequences of mutations in T82 both in vitro and in vivo, we conclude that this residue has a predominant role in cell cycle regulation of Ste11.

\section{An autocatalytic developmental switch}

The model presented in Figure 7, combining a positive feedback loop and a Cdk switch, seems particularly well suited for the regulation of irreversible decisions like developmental choices. There appears to be a built-in synergy in this pathway that drives starved cells toward expressing ever higher levels of Ste11, thereby proceeding irreversibly into sexual differentiation: Starvation induces Ste11-controlled pheromone signaling, causing $\mathrm{G}_{1}$ arrest via down-regulation of Cdk activity, which, in turn, allows unphosphorylated Ste11 to boost its own synthesis further.

Apparently, several cellular conditions need to be fulfilled before the Ste11 autocatalytic switch can become activated. First, cells need to be starved for nitrogen in order to activate transcription of the ste 11 gene independently of Ste11 itself (Takeda et al. 1995; Higuchi et al. 2002). Secondly, starvation and pheromone signaling must relieve Ste11 from repression by the Pat1 protein kinase, which allows Ste11 to enter the nucleus (Qin et al. 2003). Finally, in the present study, we have shown that low Cdk activity stimulates the DNA-binding activity of Ste11. Hence, this setup ensures that only starved cells arrested in $G_{1}$ embark on the differentiation pathway. In ste $11^{T 82 A}$ cells, only the cell cycle regulation is violated, so nitrogen starvation is still required in order to trigger the Ste11 autocatalytic loop.

\section{Cig2 as a negative regulator of differentiation}

Our results suggest that the peak in Cig2-Cdc2 activity at the $G_{1}-S$ transition is important for the timing of Ste11 down-regulation. Cig2-Cdc2 can phosphorylate Ste11 in vitro, and cells deleted for cig2 have increased Ste11 levels in vivo. This provides an explanation for several genetic observations pointing toward a negative role for Cig2 in regulation of sexual differentiation. Overexpression of Cig2 prevents $G_{1}$ arrest prior to mating (Stern and Nurse 1997) and reduces mating (ObaraIshihara and Okayama 1994), effects that have been attributed to an accelerated entry into $S$ phase. Our findings suggest that these phenotypes may be caused by down-regulation of Ste11 due to enhanced phosphorylation of T82. Cells deleted for cig2 are, on the other hand, hyperfertile (Connolly and Beach 1994; Obara-Ishihara and Okayama 1994), presumably because of their elevated Ste11 level (this study).

Table 3. Mating frequencies of $G_{1}, S$, and $G_{2}$ cells ${ }^{\mathrm{a}}$

\begin{tabular}{lcc}
\hline & ste $11^{w t}$ & ${\text { ste } 11^{\text {T82A }}}$ \\
\hline$c d c 10$ & $1.000 \pm 0.073$ & $1.270 \pm 0.235$ \\
$c d c 22$ & $0.033 \pm 0.020$ & $0.117 \pm 0.013^{\mathrm{b}}$ \\
$c d c 25$ & $0.002 \pm 0.002$ & $0.005 \pm 0.004^{\mathrm{b}}$ \\
\hline
\end{tabular}

aMating frequencies of cells arrested in $G_{1}, S$, and $G_{2}$, were estimated as described in Materials and Methods. The mating frequency of cdc10 ste $11^{\text {wt }}$ cells was set to 1.000 and used as reference. Values represent means and standard deviations (SD) of 10 separate trials.

${ }^{\mathrm{b}}$ Mating efficiencies of ste $11^{T 82 A}$ cells are significantly different from that of cells carrying a ste 11 wild-type allele $(P<0.05$; tested by paired Student's $t$-test). 
A
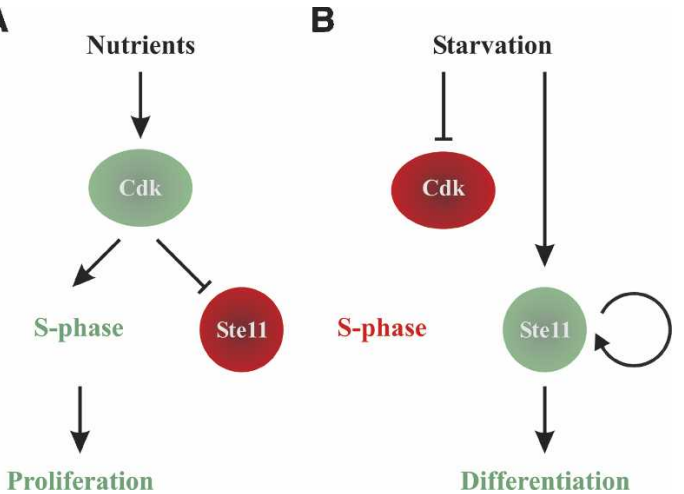

Figure 7. Model for activation of differentiation by a Cdk-sensitive autocatalytic switch. (A) When supply of nutrients is sufficient to support vegetative growth, Cdk activation in late $G_{1}$ will trigger S phase and inactivate Ste11. (B) Following nutritional starvation, Cdk activity will be down-regulated, causing $\mathrm{G}_{1}$ arrest. This also activates the Ste11 positive feedback loop that drives cells into differentiation.

It has been shown that pheromone stimulation slows down $G_{1}$ progression by down-regulating Cig2, thereby allowing accumulation of the $\mathrm{G}_{1}$-specific Cdk-inhibitor Rum1, which subsequently enforces the arrest (Stern and Nurse 1998). Since Ste11 is required for $\mathrm{G}_{1}$ arrest (Kjaerulff et al. 2005; this study), we propose that increased accumulation of Ste11 in the absence of Cig2 is important in this process.

\section{DNA binding regulated by phosphorylation}

Cdk phosphorylation of T82 prevents Ste11 from binding to its TR-box target sequence. T82 is situated immediately C-terminal to the HMG-box of Ste11, in a region that was shown to be important for interaction with bases 3' to HMG-binding core DNA sequence (van Beest et al. 2000). A stretch of basic amino acids in this region is a common feature of many sequence-specific HMGbox proteins, and according to the NMR structure of Lef1 bound to DNA, these residues contact the sugar-phosphate backbone (Love et al. 1995). Hence, it is reasonable to anticipate that phosphorylation of T82 can interfere with Ste11 DNA binding.

In addition to binding DNA, the HMG-box of Ste11 has been shown to interact with Mat1-Mc, another HMG-box protein that assists Ste11 in binding to lowaffinity sites found in M-specific genes (Kjaerulff et al. 1997). However, we found no indication that the interaction between Ste11 and Mat1-Mc was influenced by T82 status (see Supplementary Fig. S7).

The T82D mutation had severe consequences in vivo, as it almost prevented sexual differentiation. Presumably, the rudimentary mating activities we observed were caused by the residual DNA-binding capacity of the Ste $11^{\mathrm{T} 82 \mathrm{D}}$ protein. When we restored DNA binding by inserting seven copies of the Ste11-binding site in a target gene, the Ste $11^{\mathrm{T} 82 \mathrm{D}}$ protein could still induce transcription quite efficiently (see Supplementary Fig. S3).
Hence, we believe that the transcriptional activator function of the T82D mutant protein is intact.

\section{Perspectives}

The results presented in this study demonstrate that a very efficient $\mathrm{Cdk}$ switch can regulate the ability to undergo differentiation in the cell cycle. Given the evolutionary conservation of $\mathrm{G}_{1}$ control, we speculate that Cdk phosphorylation of differentiation-specific transcription factors may be a general way of repressing differentiation outside $G_{1}$. Indeed, in budding yeast, $C d k$ activity was previously shown to prevent pheromonecontrolled transcription in haploid cells (Oehlen and Cross 1994), and to down-regulate the Imel meiotic regulator in diploid cells (Colomina et al. 1999). Similarly, human muscle cell differentiation could be prevented by Cyclin D-Cdk4 phosphorylation of the transcription factor MEF2 (Lazaro et al. 2002). In the latter two cases, the inhibitory effect of Cdk phosphorylation appeared to be mediated by nuclear exclusion of the transcription factors, although the molecular mechanisms for this remain obscure.

We found that Cdk phosphorylation prevented the DNA-binding activity of Ste11. In mammalian cells, phosphorylation by Cdk2 in complex with Cyclin A or Cyclin E was similarly shown to prevent DNA binding of E2F1 and DP1, to ensure progression through S phase (Krek et al. 1994). Ste11 belongs to the family of HMGbox proteins, which are involved in many different differentiation processes (Soullier et al. 1999). Interestingly, Cdk phosphorylation of HMGI/Y, belonging to the family of sequence-unspecific HMG-box proteins, was previously shown to prevent its binding to DNA (Reeves et al. 1991; Piekielko et al. 2001), although the biological significance of this remains to be demonstrated. It will be interesting to learn whether Cdk phosphorylation of transcription factors plays a general role in restricting differentiation-specific expression to $G_{1}$.

\section{Materials and methods}

\section{Genetic procedures}

Standard genetic procedures were carried out as described previously (Moreno et al. 1991). For physiological experiments, cells were grown in MSL (Egel et al. 1994). To induce sexual differentiation, cells of a density of $2.5 \times 10^{6}$ to $5 \times 10^{6}$ cells $/ \mathrm{mL}$ were shifted to nitrogen-deficient MSL (MSL lacking arginine, MSL-N) and incubated for 2-22 h. To induce expression from the $n m t$ promoter (Maundrell 1990), transformants were grown in MSL containing $6 \mu \mathrm{M}$ thiamine, then shifted to fresh medium lacking thiamine and grown for $14 \mathrm{~h}$ before starting induction of sexual differentiation. When indicated, chemically synthesized M-factor (made by Schafer-N) was added to a final concentration of $1 \mu \mathrm{g} / \mathrm{mL}$. Strains were grown at $30^{\circ} \mathrm{C}$ unless otherwise indicated.

Mutagenesis of T82 to alanine and aspartate was accomplished using the QuikChange kit (Stratagene), pON559 as template, and the following oligonucleotides: T82A, ONP195, and ONP196; and T82D, ONP197, and ONP198; thereby creating 
pON562 and pON564, respectively. The two ste11 alleles were integrated into the ste11 loci as described previously (Kjaerulff et al. 2005).

\section{Expression vectors and recombinant proteins}

The pREP41X-Ste11 (pON817) expression vector was generated by ligating a BsrGI-XhoI fragment from pREP41X (Forsburg 1993) into BsrGI-XhoI-digested pREP3X-Ste11 (Kjaerulff et al. 1997). To construct pREP41X-Ste $11^{\mathrm{T} 82 \mathrm{~A}}(\mathrm{pON} 819)$ and pREP41X-Ste11 ${ }^{\mathrm{T} 82 \mathrm{D}}$ (pSK159), pON562 and pON564, respectively, were digested with NdeI and AvrII and ligated into NdeI/ AvrII-digested pON817. The pREP3X-GST-Ste1 $1_{1-113}$ and pREP3X-GST-Ste $11^{\mathrm{T} 82 \mathrm{~A}}{ }_{1-113}$ vectors were produced by ligating MscI-BspHI restriction fragments from pSK60 and pON572, respectively, into MscI/BspHI-digested pLB34.

GST-Ste $11^{\mathrm{T} 82 \mathrm{~A}}$ and GST-Ste $11^{\mathrm{T} 82 \mathrm{D}}$ recombinant proteins were generated as follows: An NdeI-BspEI fragment in pSK60 (encoding GST-Ste11 $1_{1-113}$ ) (Kjaerulff et al. 1997) was replaced with an NdeI-BspEI fragment from pON562 and pON564, thereby creating pON572 (pGEX-Ste $11^{\mathrm{T} 82 \mathrm{~A}}$ ) and pON570 (pGEX-Ste1 $1^{\mathrm{T} 82 \mathrm{D})}$ ), respectively. pSK60, pON570, and pON572 expression vectors were transformed into the DH5 E. coli strain. Expression and purification on glutathione-Sepharose were as described previously (Kjaerulff et al. 1997). Purification and the size of recombinant proteins were tested by SDS-PAGE followed by Coomassie staining and Western analysis. MBP-Mat1Mc has been described elsewhere (Dooijes et al. 1993).

\section{RT-PCR analysis}

Total RNA was extracted using hot acidic phenol as described by Lyne et al. (2003). To remove contaminating DNA, the RNA samples were digested with DNase I prior to RT-PCR and realtime PCR analysis. RT-PCR was carried out using $50 \mathrm{ng}$ of DNase I-treated RNA and the Qiagen OneStep RT-PCR kit. The thermal cycling conditions comprised reverse transcription for $30 \mathrm{~min}$ at $50^{\circ} \mathrm{C}$ and an initial denaturation for $15 \mathrm{~min}$ at $95^{\circ} \mathrm{C}$, followed by $20-25$ cycles of $15 \mathrm{sec}$ at $95^{\circ} \mathrm{C}, 30 \mathrm{sec}$ at $50^{\circ} \mathrm{C}$, and $60 \mathrm{sec}$ at $72^{\circ} \mathrm{C}$. The following oligonucleotides were used: mfm2, SKP47 and SKP49; act1, ONP520 and ONP521.

\section{EMSAS}

T4 polynucleotide kinase was used to label annealed oligonucleotides with $\left[\gamma_{-}{ }^{32} \mathrm{P}\right] \mathrm{ATP}$. In a binding reaction, the recombinant GST-Ste11 proteins $(1-1000 \mathrm{nM})$ were incubated in a volume of $20 \mu \mathrm{L}$ containing $10 \mathrm{mM}$ Tris (pH 8.0), $5 \mathrm{mM} \mathrm{MgCl}_{2}$, $50 \mathrm{mM} \mathrm{NaCl}, 0.1 \%$ NP-40, $0.1 \mathrm{mM}$ EDTA, $5 \%$ glycerol, $5 \mu \mathrm{g}$ of bovine serum albumin (BSA), and 200 ng of poly(dIdC). For experiments in which GST-Ste11 was first phosphorylated by cyclin/kinase complexes, 20 -min incubations $\left(30^{\circ} \mathrm{C}\right)$ were performed in the presence of $10 \mathrm{mM} \mathrm{MgCl}_{2}$ and $250 \mu \mathrm{M}$ ATP. After addition of $0.5 \mathrm{ng}$ of probe, reactions were left for $30 \mathrm{~min}$ at room temperature. Samples were electrophoresed through a $6 \%$ nondenaturing polyacrylamide gel in $0.25 \%$ TBE at room temperature. The following oligonucleotides were used: $m f m 1$ TRbox, SKP11 annealed to SKP12; strong TR-box, SKP27 annealed to SKP28; TR/M-box, SKP31 annealed to SKP32.

\section{Western analysis}

Protein extracts were made by trichloroacetic acid (TCA) precipitation as described previously (Foiani et al. 1994). Fifty micrograms of protein were loaded per lane, wereseparated using $10 \%$ SDS-PAGE, and were transferred to mixed cellulose ester membranes (Advantec). Ste11 was detected using a monoclonal anti-Ste11 antibody (Kjaerulff et al. 2005), and $\alpha$-tubulin was detected using a monoclonal anti-Tat1 antibody (Woods et al. 1989). Secondary antibody was horseradish peroxidase-conjugated rabbit anti-mouse antibody (DakoCytomation) detected with enhanced chemiluminescence (Amersham Biosciences).

\section{Kinase assays}

For kinase assays, extracts from $10^{8}$ cells were made using $\mathrm{HB}$ buffer (25 mM MOPS at pH 7.2, $15 \mathrm{mM} \mathrm{MgCl}_{2}, 15 \mathrm{mM}$ EGTA, $1 \%$ Triton X-100, 1 mM DTT, 15 mM p-nitrophenyl phosphate [pNPP], $0.1 \mathrm{mM}$ sodium vanadate, $100 \mu \mathrm{g} / \mathrm{mL}$ Pefabloc, $2 \mu \mathrm{g} / \mathrm{mL}$ leupeptin, $10 \mu \mathrm{g} / \mathrm{mL}$ aprotinin) (Moreno et al. 1991). Cells were disrupted using glass beads and a FastPrep Instrument (Bio101) at setting 6.5 for $3 \mathrm{sec}$. After cell breakage, $500 \mu \mathrm{L}$ of buffer $\mathrm{HB}$ was added, and the soluble protein fraction was recovered by two centrifugations of $10 \mathrm{~min}$ at $20,000 \mathrm{~g}$. Samples of $1 \mathrm{mg}$ of extracts were immunoprecipitated at $0^{\circ} \mathrm{C}$ for $1 \mathrm{~h}$ using $2.5 \mu \mathrm{L}$ of anti-Cdc2 (PN24), $2.5 \mu \mathrm{L}$ of anti-Cdc13 (SP4), $5.0 \mu \mathrm{L}$ of anti-Cig2 (MOC8), and $2.5 \mu \mathrm{L}$ of anti-HA (12CA5) antibodies. Fifty microliters of protein G-Sepharose were then added for $30 \mathrm{~min}$ at $4^{\circ} \mathrm{C}$, and the immunoprecopitates were washed five times with $\mathrm{HB}$ buffer. Immunoprecipitates were resuspended in $20 \mu \mathrm{L}$ of HB buffer containing $50 \mu \mathrm{M}$ ATP, $2.5 \mu \mathrm{Ci}\left[\gamma^{32} \mathrm{P}\right] \mathrm{ATP}$, and either $5 \mu \mathrm{g}$ of histone $\mathrm{H} 1$ (Calbiochem) or $5 \mu \mathrm{g}$ of recombinant Ste11 protein and incubated for $15 \mathrm{~min}$ at $30^{\circ} \mathrm{C}$. The reactions were stopped with $25 \mu \mathrm{L}$ of $2 \times$ SDS-sample buffer and denatured for 5 min at $100^{\circ} \mathrm{C}$, and samples were run on a $10 \%$ SDS-polyacrylamide gel. Phosphorylated proteins were detected and quantified using a Storm (Molecular Dynamics).

\section{Phosphopeptide analysis by MALDI-TOF mass spectrometry}

Phosphopeptide mapping and sequence analysis were performed at Alphalyse using microcapillary revers-phase high-performance liquid chromatography nanospray tandem mass spectrometry. Briefly, Stell was subjected to in-gel digestion with trypsin and the produced peptides were passed through a $\mathrm{TiO}_{2}$ microcolumn (POROS R2) in 2.5-dihydroxybenzoic acid (DHB) to enrich for phosphorylated peptides (Larsen et al. 2005). The enriched phosphopeptides were subjected to MALDI-TOF peptide mass fingerprinting and MALDI-TOF/TOF peptide sequencing.

\section{Detection of Ste11-His 6 -ubiquitin conjugates}

$m t s 3-1, m t s 3-1$ ste $11^{T 82 A}$, and $m t s 3-1$ ste $11^{T 82 D}$ strains were transformed with a plasmid expressing $\mathrm{His}_{6}$-tagged ubiquitin from the $n m t 1$ promoter (pREP1-His ${ }_{6}$-ubiquitin was obtained from S. Moreno, Salamanca, Spain). Cells were cultured at $25^{\circ} \mathrm{C}$ in absence of thiamine and shifted to $36^{\circ} \mathrm{C}$ for $4 \mathrm{~h}$ prior to harvesting. His 6 -ubiquitin conjugates were purified from $5 \times 10^{8}$ cells essential as described by Treier et al. (1994) and analyzed by Western blotting using anti-Ste11, anti-ubiquitin (gift from R. Hartmann Petersen, Copenhagen, Denmark), and anti-Cdc13 (SP4) antibodies.

\section{Mating and sporulation assay}

To determine mating and sporulation efficiency, homothallic strains were grown in MSL to a density of $5 \times 10^{6}$ cells $/ \mathrm{mL}$, then shifted to MSL without nitrogen source and incubated at $30^{\circ} \mathrm{C}$. Samples were withdrawn every hour, and the number of asci and zygotes was recorded. The efficiency of mating was calculated as the following ratio: $2 \times$ (number of asci and zygotes 
formed)/(total number of cells $+2 \times$ number of asci and $z y$ gotes).

Mating frequencies of $G_{1}, S$, and $G_{2}$ cells were measured essentially as described by Nurse and Bissett (1981). In brief, $h^{-}$ leu $1 \mathrm{cdc}$ strains were grown at $25^{\circ} \mathrm{C}$ in minimal medium, then shifted to medium lacking nitrogen source and incubated at $36^{\circ} \mathrm{C}$. After $4 \mathrm{~h}$, cells were mixed with $h^{+}$mat1-Pm ura 4 ade 6 cells and incubated at $33^{\circ} \mathrm{C}$. After overnight incubation, the mating mix was briefly sonicated and plated on minimal medium without supplements to select for complemented diploids.

\section{Flow cytometry and microscopy}

About $3 \times 10^{6}$ cells were harvested, fixed with $70 \%$ ice-cold ethanol, and processed for 4',6'-diamidino-2-phenylindole (DAPI) staining and flow cytometry, as described previously (Moreno et al. 1991; Pereira and Jones 2001) with the following exception: Prior to RNase treatment, the cells were incubated with $1 \mathrm{mg} / \mathrm{mL}$ pepsin in $0.1 \mathrm{M} \mathrm{HCl}$ for $1 \mathrm{~h}$ at room temperature (E. Boye, pers. comm.). A Becton-Dickinson FACScan was used for flow cytometry.

An Axio Imager Z.1 (Carl Zeiss) was used for microscopy, and images were captured using a cooled CCD camera (ORCA-ER; Hamamatsu) and Velocity software (Improvision).

\section{Acknowledgments}

We thank Beata Grallert, Sergio Moreno, Dieter Wolf, Rasmus Hartmann Petersen, and Masayuki Yamamoto for strains and reagents; Hanne Jørgensen and Karin Holm for expert technical assistance; and Julie Promisel Cooper, Richard Egel, and Christian Holmberg for comments on the manuscript. This work was supported by the Danish Natural Science Research Council and the Novo-Nordisk Foundation.

\section{References}

Benito, J., Martin-Castellanos, C., and Moreno, S. 1998. Regulation of the $\mathrm{G}_{1}$ phase of the cell cycle by periodic stabilization and degradation of the $\mathrm{p} 25^{\mathrm{rum} 1} \mathrm{CDK}$ inhibitor. EMBO $J$. 17: 482-497.

Booher, R.N., Alfa, C.E., Hyams, J.S., and Beach, D.H. 1989. The fission yeast cdc2/cdc13/suc1 protein kinase: Regulation of catalytic activity and nuclear localization. Cell 58: 485-497.

Colomina, N., Gari, E., Gallego, C., Herrero, E., and Aldea, M. 1999. $G_{1}$ cyclins block the Ime1 pathway to make mitosis and meiosis incompatible in budding yeast. $E M B O ~ J$. 18: 320-329.

Connolly, T. and Beach, D. 1994. Interaction between the Cig1 and Cig2 B-type cyclins in the fission yeast cell cycle. Mol. Cell. Biol. 14: 768-776.

Costanzo, M., Nishikawa, J.L., Tang, X., Millman, J.S., Schub, O., Breitkreuz, K., Dewar, D., Rupes, I., Andrews, B., and Tyers, M. 2004. CDK activity antagonizes Whi5, an inhibitor of $\mathrm{G}_{1} / \mathrm{S}$ transcription in yeast. Cell 117: 899-913.

Davey, J. and Nielsen, O. 1994. Mutations in cyr1 and pat1 reveal pheromone-induced $\mathrm{G}_{1}$ arrest in the fission yeast Schizosaccharomyces pombe. Curr. Genet. 26: 105-112.

de Bruin, R.A., McDonald, W.H., Kalashnikova, T.I., Yates III, J., and Wittenberg, C. 2004. Cln3 activates $G_{1}$-specific transcription via phosphorylation of the SBF bound repressor Whi5. Cell 117: 887-898.

Dooijes, D., van de Wetering, M., Knippels, L., and Clevers, H. 1993. The Schizosaccharomyces pombe mating-type gene
mat-Mc encodes a sequence-specific DNA-binding high mobility group box protein. J. Biol. Chem. 268: 24813-24817.

Egel, R., Willer, M., Kjaerulff, S., Davey, J., and Nielsen, O. 1994. Assessment of pheromone production and response in fission yeast by a halo test of induced sporulation. Yeast 10: 1347-1354.

Foiani, M., Marini, F., Gamba, D., Lucchini, G., and Plevani, P. 1994 . The B subunit of the DNA polymerase $\alpha$-primase complex in Saccharomyces cerevisiae executes an essential function at the initial stage of DNA replication. Mol. Cell. Biol. 14: 923-933.

Forsburg, S.L. 1993. Comparison of Schizosaccharomyces pombe expression systems. Nucleic Acids Res. 21: 29552956.

Gordon, C., McGurk, G., Wallace, M., and Hastie, N.D. 1996. A conditional lethal mutant in the fission yeast $26 \mathrm{~S}$ protease subunit $\mathrm{mts}^{+}$is defective in metaphase to anaphase transition. J. Biol. Chem. 271: 5704-5711.

Higuchi, T., Watanabe, Y., and Yamamoto, M. 2002. Protein kinase A regulates sexual development and gluconeogenesis through phosphorylation of the $\mathrm{Zn}$ finger transcriptional activator Rst2p in fission yeast. Mol. Cell. Biol. 22: 1-11.

Imai, Y. and Yamamoto, M. 1994. The fission yeast mating pheromone P-factor: Its molecular structure, gene structure, and ability to induce gene expression and $G_{1}$ arrest in the mating partner. Genes \& Dev. 8: 328-338.

Jallepalli, P.V., Brown, G.W., Muzi-Falconi, M., Tien, D., and Kelly, T.J. 1997. Regulation of the replication initiator protein $\mathrm{p} 65^{\mathrm{cdc} 18}$ by CDK phosphorylation. Genes \& Dev. 11: 2767-2779.

Kitamura, K., Katayama, S., Dhut, S., Sato, M., Watanabe, Y., Yamamoto, M., and Toda, T. 2001. Phosphorylation of Mei2 and Ste11 by Pat1 kinase inhibits sexual differentiation via ubiquitin proteolysis and 14-3-3 protein in fission yeast. Dev. Cell 1: 389-399.

Kjaerulff, S., Davey, J., and Nielsen, O. 1994. Analysis of the structural genes encoding $\mathrm{M}$-factor in the fission yeast Schizosaccharomyces pombe: Identification of a third gene, mfm3. Mol. Cell. Biol. 14: 3895-3905.

Kjaerulff, S., Dooijes, D., Clevers, H., and Nielsen, O. 1997. Cell differentiation by interaction of two HMG-box proteins: Mat1-Mc activates $M$ cell-specific genes in $S$. pombe by recruiting the ubiquitous transcription factor Stel1 to weak binding sites. EMBO J. 16: 4021-4033.

Kjaerulff, S., Lautrup-Larsen, I., Truelsen, S., Pedersen, M., and Nielsen, O. 2005. Constitutive activation of the fission yeast pheromone-responsive pathway induces ectopic meiosis and reveals Ste11 as a mitogen-activated protein kinase target. Mol. Cell. Biol. 25: 2045-2059.

Krek, W., Ewen, M.E., Shirodkar, S., Arany, Z., Kaelin Jr., W.G., and Livingston, D.M. 1994. Negative regulation of the growth-promoting transcription factor E2F-1 by a stably bound cyclin A-dependent protein kinase. Cell 78: 161-172.

Kunitomo, H., Higuchi, T., Iino, Y., and Yamamoto, M. 2000. A zinc-finger protein, Rst2p, regulates transcription of the fission yeast $s t e 11^{+}$gene, which encodes a pivotal transcription factor for sexual development. Mol. Biol. Cell 11: 3205-3217.

Larsen, M.R., Thingholm, T.E., Jensen, O.N., Roepstorff, P., and Jorgensen, T.J. 2005. Highly selective enrichment of phosphorylated peptides from peptide mixtures using titanium dioxide microcolumns. Mol. Cell. Proteomics 4: 873-886.

Lazaro, J.B., Bailey, P.J., and Lassar, A.B. 2002. Cyclin D-cdk4 activity modulates the subnuclear localization and interaction of MEF2 with SRC-family coactivators during skeletal muscle differentiation. Genes \& Dev. 16: 1792-1805. 
Lee, M.G. and Nurse, P. 1987. Complementation used to clone a human homologue of the fission yeast cell cycle control gene cdc2. Nature 327: 31-35.

Love, J.J., Li, X., Case, D.A., Giese, K., Grosschedl, R., and Wright, P.E. 1995. Structural basis for DNA bending by the architectural transcription factor LEF-1. Nature 376: 791795.

Lyne, R., Burns, G., Mata, J., Penkett, C.J., Rustici, G., Chen, D., Langford, C., Vetrie, D., and Bahler, J. 2003. Whole-genome microarrays of fission yeast: Characteristics, accuracy, reproducibility, and processing of array data. BMC Genomics 4: 27.

Martin-Castellanos, C. and Moreno, S. 1996. Regulation of $\mathrm{G}_{1}$ progression in fission yeast by the rum $1^{+}$gene product. Prog. Cell Cycle Res. 2: 29-35.

Maundrell, K. 1990. nmt1 of fission yeast. A highly transcribed gene completely repressed by thiamine. J. Biol. Chem. 265: 10857-10864.

Mondesert, O., McGowan, C.H., and Russell, P. 1996. Cig2, a B-type cyclin, promotes the onset of S in Schizosaccharomyces pombe. Mol. Cell. Biol. 16: 1527-1533.

Moreno, S., Hayles, J., and Nurse, P. 1989. Regulation of p34 ${ }^{\text {cdc2 }}$ protein kinase during mitosis. Cell 58: 361-372.

Moreno, S., Klar, A., and Nurse, P. 1991. Molecular genetic analysis of fission yeast Schizosaccharomyces pombe. Methods Enzymol. 194: 795-823.

Nielsen, O. 2004. Mating-type control and differentiation. In The molecular biology of Schizosaccharomyces pombe (ed. R. Egel), pp. 281-296. Springer, Heidelberg, Germany.

Nurse, P. and Bissett, Y. 1981. Gene required in $G_{1}$ for commitment to cell cycle and in $G_{2}$ for control of mitosis in fission yeast. Nature 292: 558-560.

Obara-Ishihara, T. and Okayama, H. 1994. A B-type cyclin negatively regulates conjugation via interacting with cell cycle 'start' genes in fission yeast. EMBO J. 13: 1863-1872.

Oehlen, L.J. and Cross, F.R. 1994. $G_{1}$ cyclins CLN1 and CLN2 repress the mating factor response pathway at Start in the yeast cell cycle. Genes \& Dev. 8: 1058-1070.

Oehlen, L.J. and Cross, F.R. 1998. Potential regulation of Ste20 function by the $C \ln 1-\mathrm{Cdc} 28$ and $\mathrm{Cln} 2-\mathrm{Cdc} 28$ cyclin-dependent protein kinases. J. Biol. Chem. 273: 25089-25097.

Pereira, P.S. and Jones, N.C. 2001. The RGS domain-containing fission yeast protein, Rgslp, regulates pheromone signalling and is required for mating. Genes Cells 6: 789-802.

Piekielko, A., Drung, A., Rogalla, P., Schwanbeck, R., Heyduk, T., Gerharz, M., Bullerdiek, J., and Wisniewski, J.R. 2001. Distinct organization of DNA complexes of various HMGI/Y family proteins and their modulation upon mitotic phosphorylation. J. Biol. Chem. 276: 1984-1992.

Qin, J., Kang, W., Leung, B., and McLeod, M. 2003. Ste11p, a high-mobility-group box DNA-binding protein, undergoes pheromone- and nutrient-regulated nuclear-cytoplasmic shuttling. Mol. Cell. Biol. 23: 3253-3264.

Reeves, R., Langan, T.A., and Nissen, M.S. 1991. Phosphorylation of the DNA-binding domain of nonhistone high-mobility group I protein by cdc2 kinase: Reduction of binding affinity. Proc. Natl. Acad. Sci. 88: 1671-1675.

Sellers, W.R., Novitch, B.G., Miyake, S., Heith, A., Otterson, G.A., Kaye, F.J., Lassar, A.B., and Kaelin Jr., W.G. 1998. Stable binding to E2F is not required for the retinoblastoma protein to activate transcription, promote differentiation, and suppress tumor cell growth. Genes \& Dev. 12: 95-106.

Sherr, C.J. 1996. Cancer cell cycles. Science 274: 1672-1677.

Soullier, S., Jay, P., Poulat, F., Vanacker, J.M., Berta, P., and Laudet, V. 1999. Diversification pattern of the HMG and SOX family members during evolution. J. Mol. Evol. 48: 517-
527.

Stern, B. and Nurse, P. 1996. A quantitative model for the cdc2 control of $S$ phase and mitosis in fission yeast. Trends Genet. 12: $345-350$.

Stern, B. and Nurse, P. 1997. Fission yeast pheromone blocks S-phase by inhibiting the $\mathrm{G}_{1}$ cyclin B-p34 $4^{\text {cdc2 }}$ kinase. EMBO J. 16: 534-544.

Stern, B. and Nurse, P. 1998. Cyclin B proteolysis and the cyclin-dependent kinase inhibitor rum $1 \mathrm{p}$ are required for pheromone-induced $\mathrm{G}_{1}$ arrest in fission yeast. Mol. Biol. Cell 9: 1309-1321.

Sugimoto, A., Iino, Y., Maeda, T., Watanabe, Y., and Yamamoto, M. 1991. Schizosaccharomyces pombe ste $11^{+}$encodes a transcription factor with an HMG motif that is a critical regulator of sexual development. Genes \& Dev. 5: 19901999.

Takeda, T., Toda, T., Kominami, K., Kohnosu, A., Yanagida, M., and Jones, N. 1995. Schizosaccharomyces pombe atf1 ${ }^{+}$encodes a transcription factor required for sexual development and entry into stationary phase. EMBO J. 14: 6193-6208.

Thomas, D.M., Carty, S.A., Piscopo, D.M., Lee, J.S., Wang, W.F., Forrester, W.C., and Hinds, P.W. 2001. The retinoblastoma protein acts as a transcriptional coactivator required for osteogenic differentiation. Mol. Cell 8: 303-316.

Treier, M., Staszewski, L.M., and Bohmann, D. 1994. Ubiquitindependent c-Jun degradation in vivo is mediated by the $\delta$ domain. Cell 78: 787-798.

van Beest, M., Dooijes, D., van De Wetering, M., Kjaerulff, S., Bonvin, A., Nielsen, O., and Clevers, H. 2000. Sequencespecific high mobility group box factors recognize 10-12base pair minor groove motifs. J. Biol. Chem. 275: 2726627273.

Watanabe, Y., Shinozaki-Yabana, S., Chikashige, Y., Hiraoka, Y., and Yamamoto, M. 1997. Phosphorylation of RNA-binding protein controls cell cycle switch from mitotic to meiotic in fission yeast. Nature 386: 187-190.

Watanabe, Y., Yokobayashi, S., Yamamoto, M., and Nurse, P. 2001. Pre-meiotic S phase is linked to reductional chromosome segregation and recombination. Nature 409: 359-363.

Weinberg, R.A. 1995. The retinoblastoma protein and cell cycle control. Cell 81: 323-330.

Woods, A., Baines, A.J., and Gull, K. 1989. Evidence for a $\mathrm{Mr}$ 88,000 glycoprotein with a transmembrane association to a unique flagellum attachment region in Trypanosoma brucei. J. Cell Sci. 93: 501-508.

Yamamoto, M. 2004. Initiation of meiosis. In The molecular biology of Schizosaccharomyces pombe (ed. R. Egel), pp. 297-309. Springer, Heidelberg, Germany.

Yamano, H., Kitamura, K., Kominami, K., Lehmann, A., Katayama, S., Hunt, T., and Toda, T. 2000. The spike of S phase cyclin Cig2 expression at the $\mathrm{G}_{1}-\mathrm{S}$ border in fission yeast requires both APC and SCF ubiquitin ligases. Mol. Cell 6: 1377-1387.

Zhang, P., Wong, C., Liu, D., Finegold, M., Harper, J.W., and Elledge, S.J. 1999. p2 $1^{\mathrm{CIP} 1}$ and $\mathrm{p} 57^{\mathrm{KIP} 2}$ control muscle differentiation at the myogenin step. Genes \& Dev. 13: 213-224. 


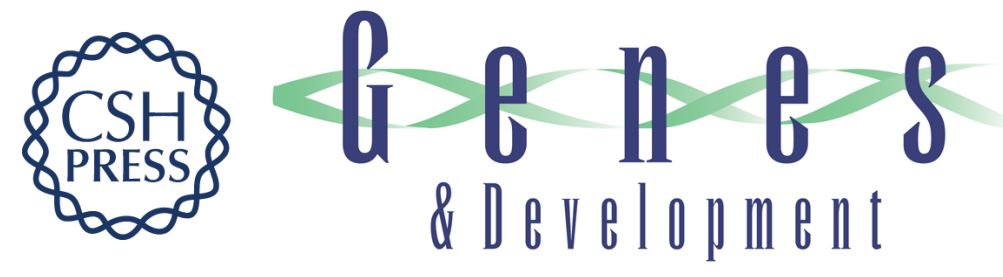

\section{Cdk phosphorylation of the Ste11 transcription factor constrains differentiation-specific transcription to $G_{1}$}

Søren Kjærulff, Nicoline Resen Andersen, Mia Trolle Borup, et al.

Genes Dev. 2007, 21:

Access the most recent version at doi:10.1101/gad.407107

Supplemental
Material http://genesdev.cshlp.org/content/suppl/2007/02/08/21.3.347.DC1

References This article cites 56 articles, 30 of which can be accessed free at:

http://genesdev.cshlp.org/content/21/3/347.full.html\#ref-list-1

License

Email Alerting Receive free email alerts when new articles cite this article - sign up in the box at the top

Service right corner of the article or click here.

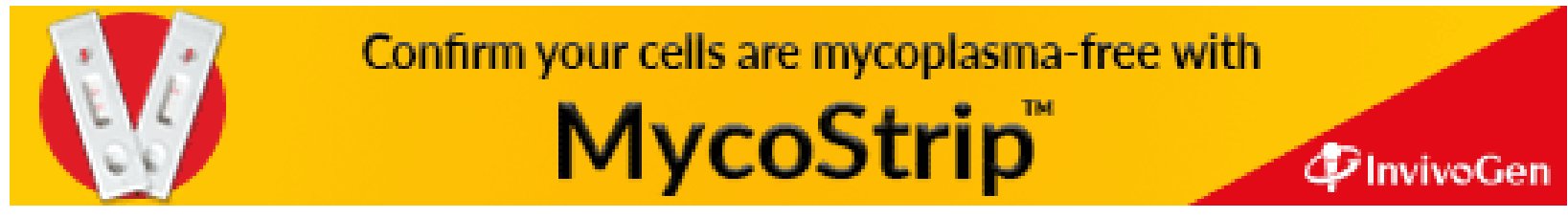

